\title{
$\mathbf{R}$ 型試験片を用いた引張試験による 超塑性特性の評価
}

\author{
古城紀雄* 高山善匡** 杜澤 達美** \\ 加藤一** 小野和人 ${ }^{\dagger}$ \\ *大阪大学工学部材料物性工学科 \\ **宇都宮大学工学部機械システム工学科
}

J. Japan Inst. Metals, Vol. 57, No. 1 (1993), pp. 29-35

\section{Evaluation of Superplastic Characteristics by means of Tensile Test of R-type Specimen}

\author{
Norio Furushiro*, Yoshimasa Takayama**, Tatsumi Tozawa**, \\ Hajime Kato** and Kazuto Ono**
}

\begin{abstract}
*Department of Materials Science and Engineering, Faculty of Engineering, Osaka University, Suita
${ }^{* *}$ Deparment of Mechanical Systems Engineering, Faculty of Engineering, Utsunomiya University, Utsunomiya

In order to evaluate the basic characteristics of superplastic materials, an R-type specimen has been proposed, which has no ordinary gauge part of a uniform cross section.

First, the fundamental problems of a conventional evaluation method have been pointed out. Then, the superplastic characteristics of a $\mathrm{Zn}-\mathrm{Al}$ eutectoid superplastic alloy have been examined to investigate the possibility of the new evaluation method using the R-type specimen.

As a result, it is found that the $\mathrm{R}$-type specimen has the excellent possibility. In particular, the extremely high elongation can be estimated from a peak value of strain distribution after fracture. Moreover, true stress versus true strain rate relation and $m$-value in a wide range of strain rate can be derived from the results for a pair of $\mathrm{R}$ type specimens.
\end{abstract}

(Received July 6, 1992)

Keywords: superplasticity, evaluation, R-type specimen, tensile test, zinc-aluminum eutectoid alloy

\section{I. 緒言}

超塑性材料の基本的な特徽は，巨大な破断伸びを示すこと特 よび変形応力のひずみ速度感受性指数 $m$ 值が通常の高温变形 の場合よりも高いことである。加えて，変形応力が低くその汪 とんどが加工硬化しないことも超塑性による成形加工に有用な 特徴である、したがって基本的な超塑性特珄としては，破断伸 び, 変形応力のひずみ速度依存性 ( $m$ 值) 括よび変形応力ーひず み関係が挙げられる。

これらの超塑性特性の評価は通常引張試験によりなされてき た.しかしながら，異常に高い延性に起因して超塑珄材料の特 性評価は一般の引張試験法では困難である場合が多い。したが って, 超塑性特性は, $m$ 值測定法, 試験片形状, 定ひずみ速 度試験(1)などにみられるよらに，試験装置希るいは試験方法の

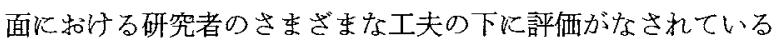
のが現状である。艺の結果として，特性評俩の方法は捛のずと

†宇都宮大学大学院生
個別化・細分化され，標準的な評価方法は統一されていない。 このことは, 通常の一般的な形状の試験片を用いた引張試験を 超塑性材料の特性評価に採用することがさをざをな問題をはら んでいることを意味するるのともいえる。

そこで，本研究では，まず通常の試験片を用いた引張試験に よる超塑性材料の特性評価比ける問題点整理する. 次にこ れを踏をえ, 問題点を解決し得る試験片として「R型試験片」 を提案するとともにこの $\mathrm{R}$ 型試験片を用いた引張試験に上 る特性評価の可能性について検討する。

\section{II．通常の試験片を用いた引張試験による超塑性特性 評価の問題点}

\section{1. 試験装置上の問題点}

超塑性村料の引張試験は高温に括いて引張速度一定の条件で なされるのが一般的である。超塑性特性は温度とひずみ速度に 強く依存することが知られて和り，試験に特いてこれらを高精 度に制御することが重要となる。よって，特に破断伸びの大き な超塑性材料を破断するまで引っ張るためには，均一に制御さ 
れた長い帯域を持つ加熱炉が必要となる，例えば，平行部長さ $20 \mathrm{~mm}$ の試験片が $1500 \%$ 伸びるとすると，少なくとも 320 $\mathrm{mm}$ の均熱帯を有するかなり長い加熱炉が必要となる．このよ らな炉には複数の制御器による温度制御が不可欠となる.

また，前に述べた定ひずみ速度試験は，ひずみ速度に強く依 存する超塑性特性の評価および変形機構の解明のために考案さ れたものであり，理想的な試験方法であると考穴られる．しか しながら，定ひずみ速度を実現するためには，時々刻々と変化 する試験片の標点間距離に応じてクロスヘッド速度を速くする 特殊な引張速度制御が必要である.

加えて，注とんどの場合このクロスヘッド速度制御はゲージ 部の均一変形を前提としているが，この前提と実際の実験結果 が異なる例も報告されている(2).よって，仮にクロスヘッド速 度をこのように制御できたとして子真の「定ひずみ速度」試験 がなされていない場合も有り得る.

このように，理想的な超塑性特性試験には極めて特殊な装置 を必要とし，比較的簡便に行えることを要求される標準的評価 法には必ずしも適当とはい觉ない。

\section{2. 試験法上の問題点}

試験法上の問題点としては，ひずみ速度の表現方法が挙げら れる．前述のように，ひずみ速度は超塑性特性を左右する重要 な因子の一つであるが，その試験条件の表現は必ずしも完全と は言えない，すなわち，通常引張速度一定試験に括いてはひず み速度が徐々に減少すると理解されて括り,ひずみ速度は試験 開始時の初期ひずみ速度で表現されている.しかし，この初期 ひずみ速度は引張速度と試験前の試験片寸法から便宜的に求め られるものであり，その定義も必ずしも明確とはい亲ない。さ らに，初期ひずみ速度と試験片の実際のひずみ速度との関係は 後述のように試験片形状に依存しており，この点も大きな問題 である。

また，超塑性特性を評価する上で極めて重要なパラメータと してひずみ速度感受性指数 $m$ が挙げられる. $m$ 值の測定法と しては, 速度変化試験法, 定速度試験法, 応力緩和試験法など 数種類の方法が提示されている( ${ }^{(3)}$. これらの測定法については $m$ 値のバラッキと破断伸びとの相関性の両面からその信頼性 が検討され，測定法の統一に関する提言がなされてはいる(3)(4) が, いまだ統一されるには至っていない,ささらに, 定速度試験 法による $m$ 值の算出の際に用いられる応力としては, 定常状 態の变形応力といら意味でしばしば最大応力が採られるが，一 方である与兄れたひずみに括ける変形応力を用いるべきであ るとの考方もあり，問題を残すものとなっている.

加えて, 試験法上の最も重要な問題として試験片形状の影響 が挙げられる。これについては，次節に詳述することにする。

\section{3. 試験片形状に関する問題点}

これまでの超塑性に関する研究ではさまざまな形状の試験片 が用いられている. その理由は以下のように理解される。 引張 試験片は本来 1 軸応力状態を実現するため, 長い平行部を設 けることが基本である. また，平行部の一様な変形を保証する ために十分に大きい肩半径をとることが必要である。しかし， 超塑性特性の評価のためには，(1)試験片を破断させるために，
加熱炉の均熱帯の長さとの関係から平行部をかなり短くとった り，あるいは(2)正確なひずみ速度制御の観点から $\mathrm{R}$ 部の变形 を避けるために，極端に肩半径を小さくとることもしばしばな される.これらにより, 当然ながら変形中 1 軸応力状態が保 持されないことも有り得ると考えられるが, 超塑性特性評価の 特殊性として認められてきている. したがって, 研究者が「通 常の引張試験片形状」と「超塑性特性評価の特殊性」といら相 反する条件のいずれを重要視するかにより,さまざまな試験片 形状が選ばれるものと理解される.

以下に, 試験片形状に関する問題点として, 破断伸び, 変形 応力拉よび $m$ 值に及ぼす試験片形状の影響について述べる.

超塑性材料の破断伸びが試験片形状に左右されることはよく 知られている. 超塑性7475アルミニウ.ム合金の実験結果 ${ }^{(5)}$ に よれば, 板厚と平行部幅の増加により破断伸びは大きく増加 し, ゲージ部長さの増加に伴い幾分減少するとされている.こ のような傾向はすべての超塑性材料にみられるものであろう.

著者の一部は, $\mathrm{Zn}-\mathrm{Al}$ 共析超塑性合金を用いて実験とコンピ ュータ・シミュレーションにより変形応力に及ぼす試験片形状 の影響を検討し, 次のような結果を得ている(6). すなわち, 超 塑性材料の変形応力は試験片形状の変化により $20 \%$ 以上もの 扣和きな変化を示した．このよらな変形応力の変化は, 試験片 形状の変化が試験片内の真ひずみ速度分布の变化をもたらした 結果であると理解される.

$m$ 值に及ぼす試験片形状の影響は他の力学的特性への影響 と対応するものであると考学られるが，その系統的な研究は少

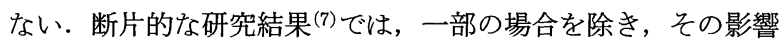
は小さいとされている.しかしながら，明確な結論を得るため にはより詳細かつ系統的な検討が必要であると考兄らる。

以上のように，試験片形状は超塑性特性に大きな影響を及ぼ すと考えられ，その決定は超塑性特性評価にとって極めて重要 な問題である.

\section{III. $\mathbf{R}$ 型試験片を用いた引張試験による超塑性特性評 価の可能性}

\section{1. $\mathbf{R}$ 型試験片とその意義}

今回提案する「R型試験片」は, Fig. 1 のように, 通常の 板状引張試験片の平行部を取り除いた形状である。このような 試験片形状は疲労試験にしばしば用いられて扔り，JIS 規格 ${ }^{(8)}$ 抢よびASTM 規格 ${ }^{(9)}$ と打いて疲労試験片として規定されてい る. また，変形様式を変化させる目的等の特殊な用途ではある が， R 型試験片が引張試験片として使用された例もいくつか

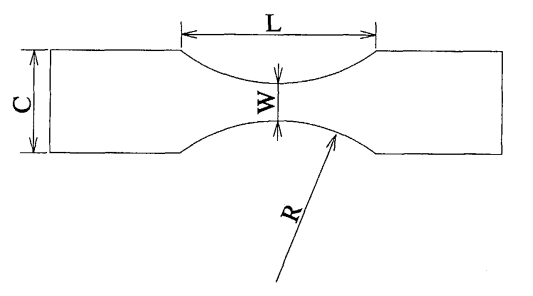

Thickness t

Fig. 1 Shape and dimensions of the R-type specimen. 
みられる(10)-(13)。しかしながら，超塑性特性評価の目的で用 いられた例はみあたらないようである。

II章で述べたように，通常の試験片による超塑性材料の特性 評価にはいくつかの問題点がある. 特に，3 節で述べた試験片 形状の影響のらち，試験片内のひずみ速度分布は重要である. 実際の試験におけるひずみ速度を正確に求めるためには，引張 速度と試験前の試験片寸法から形式的に求めるのではなく，な んらかの方法で実測した寸法変化から求めることが必要であろ う.この観点から, 比較的簡便な方法として, 所定の時間で試 験を中断し, 試験前後の試験片の寸法変化を測定することによ り，ひずみ速度を求めることが考えられる．この方法により， 平均的なひずみ速度は確実に測定できる. 一方, 通常の試験片 に执いて肩半径 $R$ が大きい場合には $\mathrm{R}$ 部がかなり変形し，平 行部のひずみ速度がその分だけ小さくなることが明らかにされ ている(6).よって， R 部にはその断面積に対応したひずみ速 度が分布していることになる．このひずみ速度分布を中断試験 法により測定し積極的に利用しょうとするのが， $\mathrm{R}$ 型試験片 の発想の原点である.

また，このような見方もできる，超塑性变形に执いては，変 形応力のひずみ速度依存性が非常に大きく, ネッキングの発達 が抑制される(14) という考光方はよく知られている．R 型試験 片による引張試験はまさにこのネッキングに対する抑制抵抗を 調べる実験でもある。したがって， $\mathrm{R}$ 型試験片を用いた引張 試験法は原理的に不可欠・最適な超塑性特性の評価法であると もいえる。

\section{2. $\mathbf{R}$ 型試験片による超塑性特性評価の特長}

前述のように, $\mathrm{R}$ 型試験片による本特性評価の最大のメリ ットは, 試験片内のひずみ速度分布を利用して複数の变形条件 に拈ける特性を評価できることにある，検討すべき点は残され ているが，1本の試験片により，広範囲のひずみ速度条件のデ 一タが一度に得られる点は, 試験の簡便さもさることながら最 も強調されるべき特長であろう。

次に， $\mathrm{R}$ 型試験片であるため，中央部にひずみが集中し， 試験片全体としては破断伸びが小さくなる. したがって, 非常 に大きい破断伸びを示す超塑性材料についても標準的な寸法の 加熱炬を用いた試験が可能となる.

また，一般に，ばらつきが大きいと考兄られる破断伸びの再 現性の向上も期待される.ささに, 試験片の破断形状は主とし て変形応力のひずみ速度依存性を反映するものと考兄られるこ とから, この破断形状の詳細な解析による超塑性特性把握の可 能性も考えられる. 加えて, 試験片の加工工程が単純であり, 高精度の加工が期待できる.

\section{3. $\mathbf{R}$ 型試験片の応力状態}

$\mathrm{R}$ 型試験片は平行部を取り除いた試験片形状であるため中 央部断面で面積が最小となり, 中央部に応力集中を生じる ${ }^{(15)}$. しかし， $\mathrm{R}$ 部半径 $R$ が相対的に大さい場合には応力集中はさ ほど大さいものではない. 例光ば, $R=25 \mathrm{~mm}, W=6 \mathrm{~mm}$, $C=16 \mathrm{~mm}$ の試験片の場合には中央部の応力集中率 $\alpha$ (=最大 応力/平均応力) 1.09 にすぎない. 同様の寸法で平行部がある 通常の試験片では $\mathrm{R}$ 部に最大応力集中点が存在し, その点の $\alpha$ は1.12で，むしろ R 型試験片の場合よりわずかながら大き い.よって，Rが十分に大きければ， $\mathrm{R}$ 型試験片に拈ける応力 集中は，通常の試験片のそれに比べ，特に問題になるものでは ないといえる。

前述の上らに通常の試験片に括いては，平行部幅に対し十分 に長い平行部が設けられていれば, 1 軸応力状態が保たれる. この前提のもとに, 材料の基本的な力学的特性を評価すること が可能となる. しかし， $\mathrm{R}$ 型試験片に扣いては，変形部分す なわち $\mathrm{R}$ 部分は 1 軸応力状態とはならず，2 軸応力状態とな る. この場合, 引張軸に垂直な方向の応力の大きさが問題であ る. $R$ が十分に大きければ部分的には平行部のある通常の試験 片に近い状態となるから，この応力は引張軸方向の応力に比べ て小さいものと考觉らるが，この点についてはさらに検討す る予定である.

\section{4. $\mathbf{R}$ 型試験片を用いた引張試験結果}

ここでは, 特性評価の可能性を検討するため， 5 種類の $\mathrm{R}$ 型試験片を用いた実際の試験結果を示す.

\section{(1) 実験方法}

試料には，典型的な超塑性材料の 1 つである $\mathrm{Zn}-\mathrm{Al}$ 共析合 金の圧延板材（板厚 $t=1 \mathrm{~mm}$ )を用いた．この板材より，Fig. 1 に示すような $\mathrm{R}$ 型試験片を切り出した。ここで, $\mathrm{R}$ 部半径 $R=25 \mathrm{~mm}$ 一定とし， $\mathrm{R}$ 部幅 $W=6 \mathrm{~mm}$ ，つか及部幅 $C$ を 10 , $12,16,20 \mathrm{~mm}$ と変化させ, さらに $W=4 \mathrm{~mm}, C=20 \mathrm{~mm}$ を 加えた計 5 種類の形状を用いた. $W=6 \mathrm{~mm}$ の形状では $C$ の 変化に伴い, $\mathrm{R}$ 部長さ(標点間距離) $L$ はそれぞれ 19.6, 23.7, $30.0,34.7 \mathrm{~mm}$ となる. 簡単のため後述の実験結果は $W=4$ $\mathrm{mm}, C=20 \mathrm{~mm}$ の形状についても $L$ の值, $36.7 \mathrm{~mm}$ により整 理した. 機械加工した試験片は, 試験中の静的な粒成長を抑制 するため, $533 \mathrm{~K}-14.4 \mathrm{ks}$ 保持後空冷の熱処理を施し, 試験に 供した.

引張試験は, 温度 $473 \mathrm{~K}$, 引張速度 $5.0 \times 10^{-6}, 1.7 \times 10^{-5}$, $1.7 \times 10^{-4}$ 打よび $1.7 \times 10^{-3} \mathrm{~m} \cdot \mathrm{s}^{-1}$ の条件で行った。一部の試 験片については, 所定の変位(時間)で試験を中断する試験を行 った。な抏，試験片のつかみ部は， $\mathrm{R}$ 部の端むでヤスリ式チ ヤックにより固定し， $\mathrm{R}$ 部以外はほとんど変形しない状態で 引張試験を行った.

試験片 $\mathrm{R}$ 部には，最小断面積を有する中央を基点として 3 $\mathrm{mm}$ 間隔に標点を設け, 所定の変位(時間)で試験を中断した後 あるいは破断後に，板幅方向中央のひずみ分布を測定した．

\section{(2) 解析方法}

本研究では $\mathrm{R}$ 型試験片といら特殊な形状の試験片について, ひずみ分布，ひずみ速度分布，さらには応力-ひずみ速度関係 を求めるため, 次のよらにデータの解析を行った.

まず，ひずみ分布は，以下のように求められる， R 型試験 片について，各ケガキ線間の平均的なひずみを求めることは可 能であるが，断面積が一様でないため，そのひずみに対応する 位置を決定することは容易ではない，したがって，そのひずみ に対応する応力を求めることも困難である. そこで，区分的多 項式補間の 1 つである 3 次のスプライン補間(16)を用いて, 各 標点上のひずみを導出した。すなわち, Fig. 2 のように横軸 を引張試験前の標点間隔にとり, 最初の標点を原点 $\left(a_{0}=0\right)$ と 


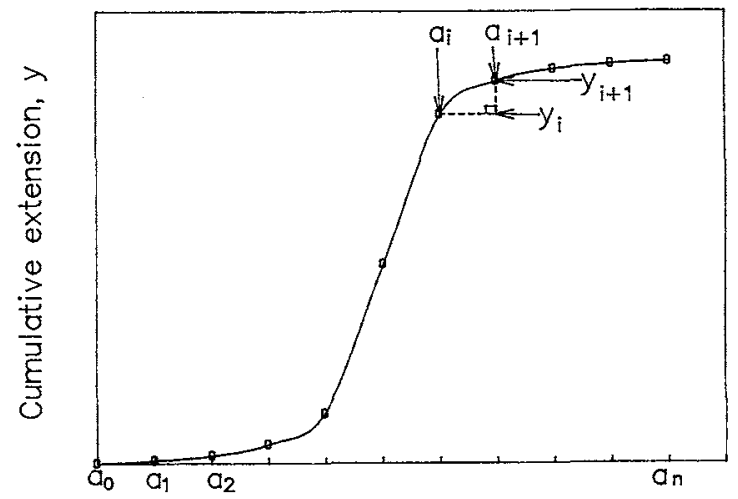

Original distance from the first gauge mark, $x$

Fig. 2 Cubic spline interpolation of the cumulative extension.

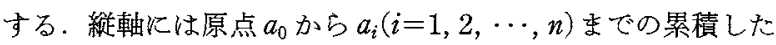
伸びをとる、このとき，スプライン補間により描かれた曲線の 接線の傾きが，各標点に执々る公称ひずみを表すことになる。

次に，ひずみ速度分布は，以下の上うに計算した。求められ た公称ひずみを真ひずみに変換し，各標点に就いて 3 次のス プライン補間により真ひずみ-時間曲線を求める，そして，得 られた曲線の接線の傾きとして真ひずみ速度を計算した。

応力の計算は各標点の断面に乱いて，荷重老断面積で除した 平均応力とした求めた。この解析方法化上り，応力とひずみ速 度が明確に対応づ方光。

\section{(3) 実験結果}

Fig. 3 K，最も基本的な引張試験結果である公称応力-変位

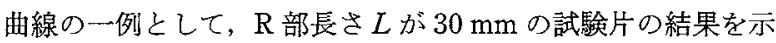
す。な拉，公称応力は荷重を $\mathrm{R}$ 部の最小原断面積で割った値 とした．図のように，引張速度の変化に伴う変形応力の変化は 極めて大きく，超塑性材料の特徵をよく表している。屯た，概 して言えば，通常の試験片による公称応力-変位曲線と比較し て特徽的な形状の差違は認められない。このことは， $\mathrm{R}$ 型試 験片における变形部のひずみ速度履歷が通常の試験片と同様に

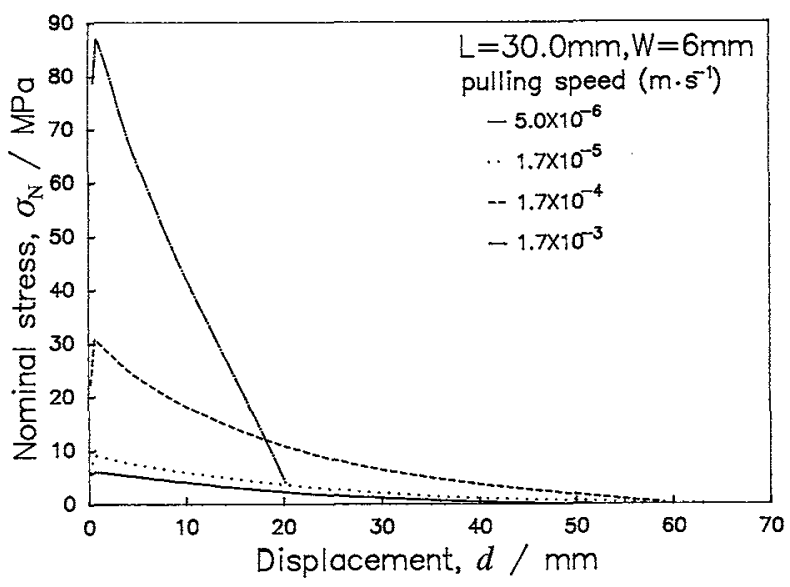

Fig. 3 Nominal stress-displacement curves of the R-type specimen with $L=30 \mathrm{~mm}$.
滑らかでしか子同傾向であることを意味している。ただし，破 断までの变位が小さいことから，中央部のひずみ速度が通常の 試験片よりも大きくなっていることは明らかである。

Fig. 4 は，5種類の R 型試験片の最大公称応力を示してい る. $W=6 \mathrm{~mm} の 4$ 種類の試験片についてみると, 最大公称応 カは $\mathrm{R}$ 部長さ $L$ にととど依存しないことがわかる。このこ

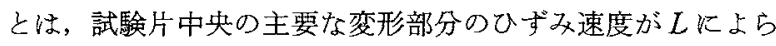
ず注涪等しいことを示すものであると考えられるＷの影響 は幾分及られ，W=4 $\mathrm{mm}, L=36.7 \mathrm{~mm}$ の試料の応力は $W=6 \mathrm{~mm}$ の試験片と比べて大きい傾向にある。

Fig. 5 は，同様に，R型試験片の破断伸びを示したもので ある、ここで， $\mathrm{R}$ 型試験片の破断伸びは， $\mathrm{R}$ 部長さ $L$ の变化 より求めた．各引張速度に执いて，Lの増加に伴い，破断伸び は大きく減少する㑯向を示した，Lの増加は， $\mathrm{R}$ 部の平均的な ひずみ速度を隇少させ，それにより破断伸びが変化すると推測 される、しかし，いわゆる Region III (17)の条件と考光られる 引張速度 $1.7 \times 10^{-3} \mathrm{~m} \cdot \mathrm{s}^{-1}$ K执いても，Lの堌加とともに破断 伸びが減少していることから，平均的なひず速度の変化の影 響は小さいといえる。このような結果は， $L$ の増加によって， 局部的な伸びの絶対量は大きく変化せず，洼とんど変形しない 領域が増加するためと理解される。 また，最大荷重と同様に， $W$ の影響がみられ，Wの異なる $L=34.7 \mathrm{~mm}$ から $L=36.7$

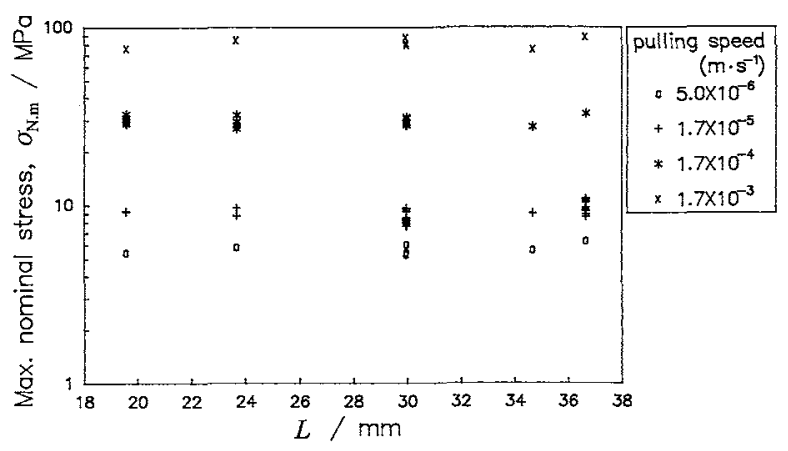

Fig. 4 Effect of the gauge length, $L$, on maximum nominal stress for the R-type specimen.

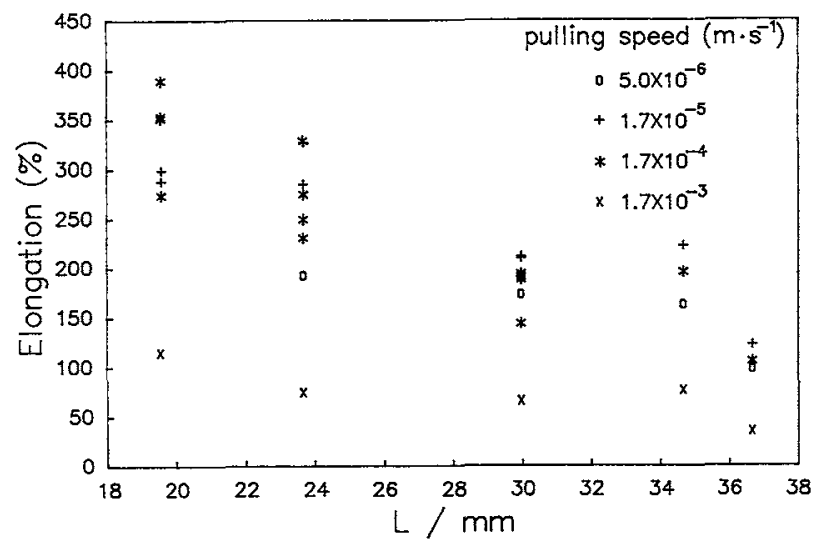

Fig. 5 Effect of the gauge length, $L$, on elongation for the R-type specimen. 
$\mathrm{mm}$ の間で試料の伸びは大さく減少している.

試験片 R 部の破断後のひずみ分布を Fig. 6 亿示す． R 部に $3 \mathrm{~mm}$ 間隔にもらけた標点について, 各標点間の平均公称ひず みを図示した，ここで, 図中の右方向が実際の引張試験に括け る上方向である. 各試験片とも, 当然ながら中央付近にひずみ が集中して特り，(d)の $\mathrm{R}$ 部長さ $L=34.7 \mathrm{~mm}$ の試験片の引張 速度 $1.7 \times 10^{-5} \mathrm{~m} \cdot \mathrm{s}^{-1}$ では $1600 \%$ ものびみが得られている. この值は，本合金について報告されている破断伸びの最大值 $2900 \%{ }^{(18)}$ と比較して考劣れば, 平行部を有する通常の試験片 により求められる破断伸びと注湆対応していると思われる.

また，各試験片に括いて，引張速度すなわらひずみ速度の違 いによりひずみ分布が大きく異なることは明らかである。この 中で，(a)の $L=19.6 \mathrm{~mm}$ の試験片ではひずみ分布のピーク位 置が中央から大きくはずれた例がみられ，全体に分布に広がり が大きい。このよらな特徵は平行部を有する試験片によくみら
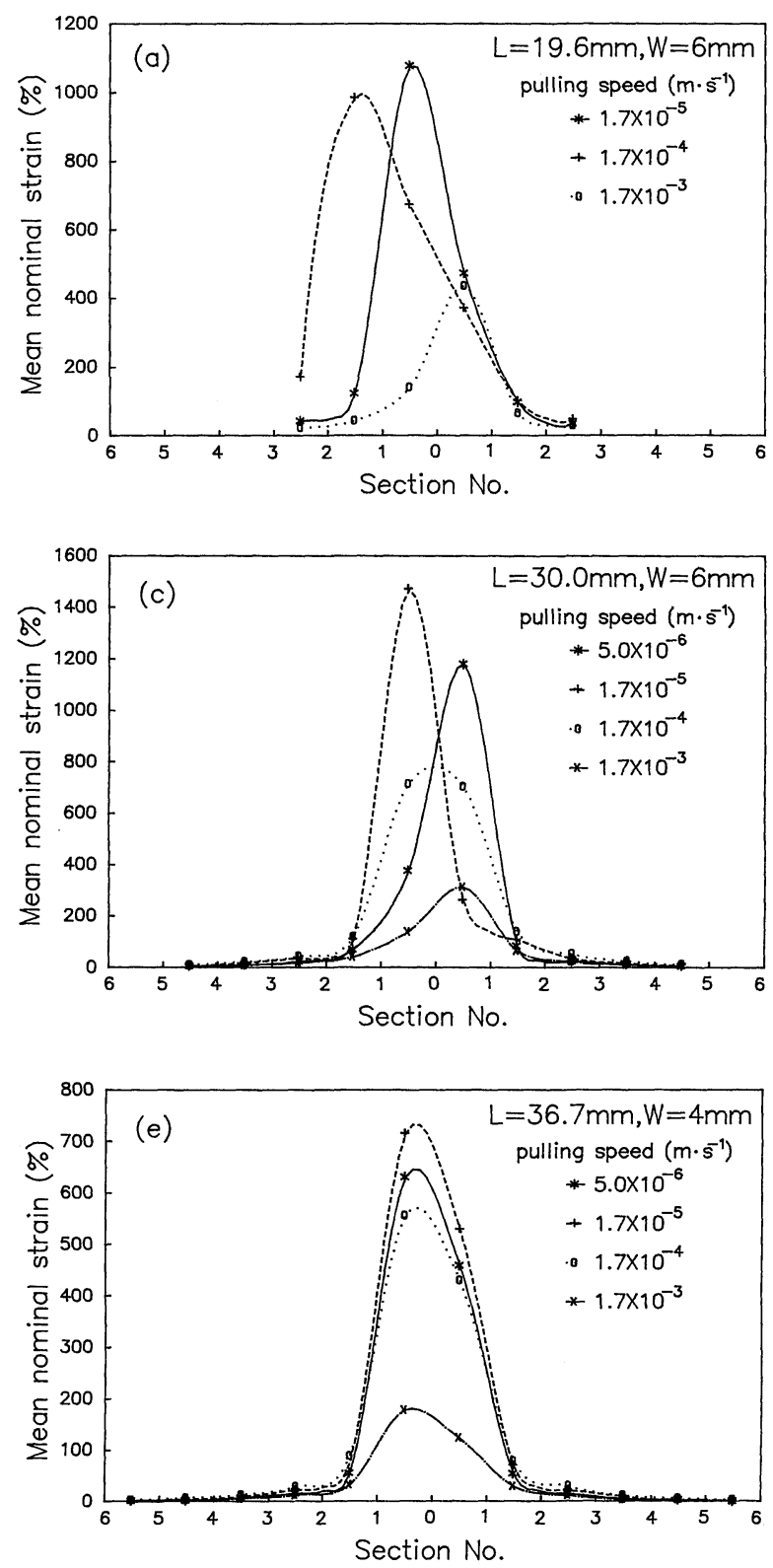

れるものであり，(a)試験片の形状の変形挙動が平行部を有す る試験片のそれに近いためであると理解される。一方，(e)試 験片はピーク位置が引張速度によらず整っており， R 型試験 片の特徵をよく表している. しかしながら，平均ひずみの最大 值は他の試験片に比べて小さい傾向となっている．これは，3 $\mathrm{mm}$ の標点間距離に対し，W=4 mm である(e)試験片の最小 幅周辺へのひずみ集中の度合いが大きいためであると考兄られ る.この点に関しては,ひずみの集中と適切な標点間距離の関 係を十分に検討する必要があると考光られる.

\section{(4) 考 察}

超塑性材料の破断伸びは，一般に顕著なひずみ速度依存性を 示す. そこで，Fig. 5 と 6 の実験結果に関してひずみ速度依存 性を調べ，延性の指標としての有用性を検討する．Fig. 7 は， $\mathrm{R}$ 型試験片の破断伸びを引張速度に対してプロットし直した ものである。また，Fig. 8 には，ひずみ分布のピークの值すな
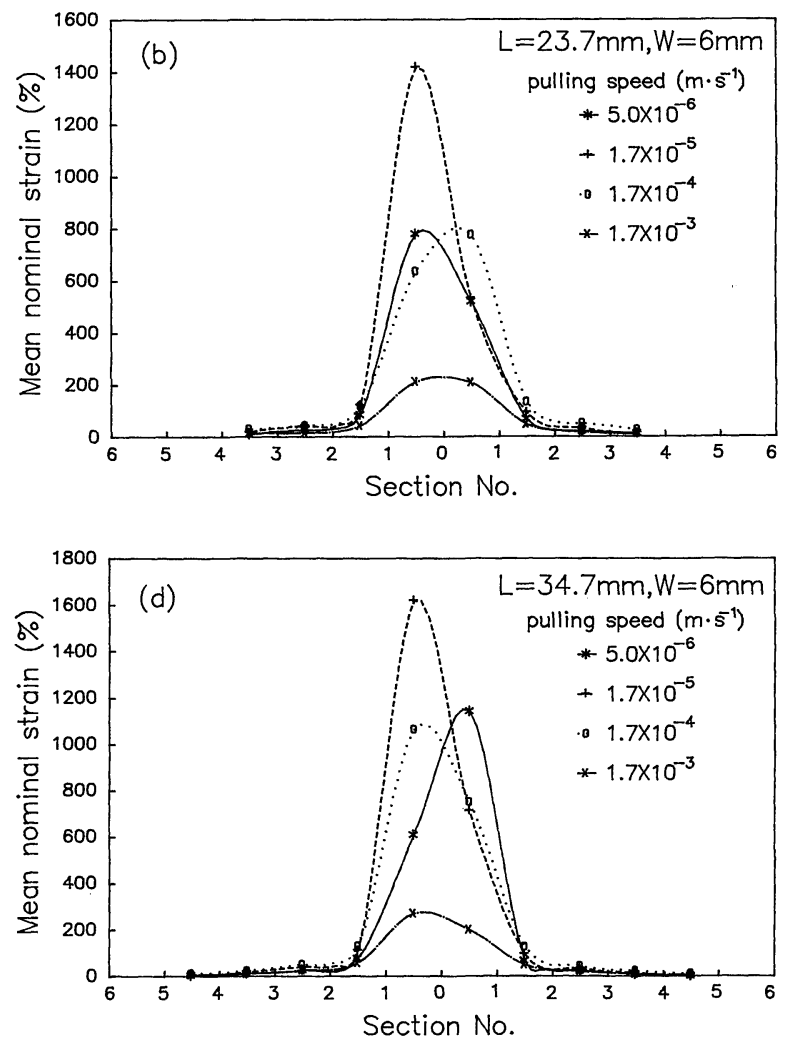

Fig. 6 Strain distributions in the gauge part of the R-type specimen after fracture under various conditions: the section numbers on the horizontal axis refer to the gauge marks dividing the original gauge part into the segments 3 $\mathrm{mm}$ long, which are numbered from 1 about the mid-point of the specimen. 


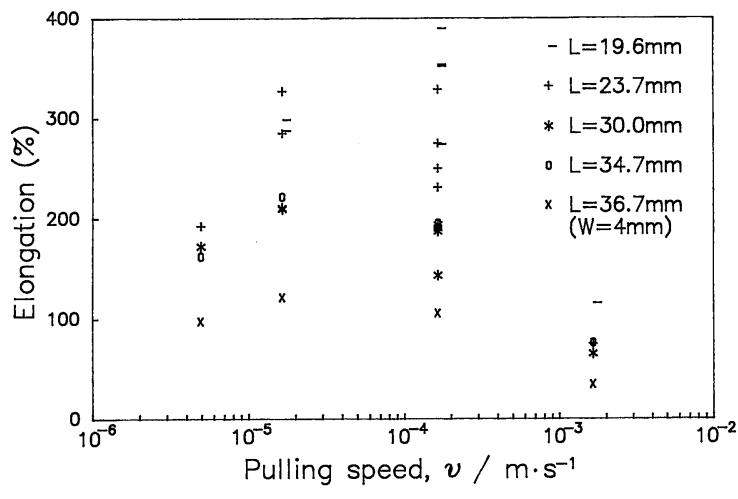

Fig. 7 Relationship between the elongation and the pulling speed for the R-type specimen.

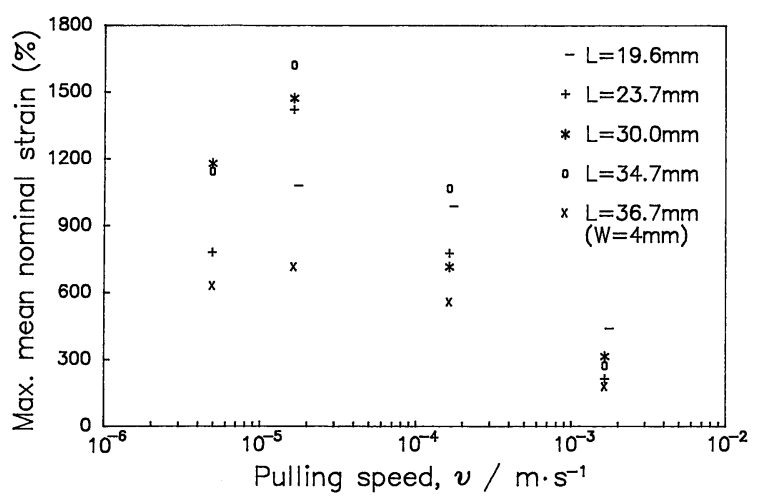

Fig. 8 Relationship between the maximum mean nominal strain and the pulling speed for the R-type specimen.

わち最大平均公称ひずみを引張速度に対して図示した.

Fig. 7 のように R 型試験片の破断伸びは明確なひずみ速度 依存性を示して拉り, 破断伸びの簡便な評価には有効であると 考光られる。しかし， $\mathrm{R}$ 部長さ $L$ が小さい試験片では值に大 きなばらつきがみられる点で，問題を残している．さらに， 「通常の試験片の破断伸び」あるいは後述の最大平均公称ひず みの变化と比較すると, 破断伸びの引張速度に対する変化の度 合いはかなり小さい傾向がみられる.したがって，この值か ら，「通常の試験片の破断伸び」を推定し定量的に評価するこ とは難しいと思われる.

これとは対照的に, Fig. 8 の最大平均公称ひずみは，ひず 又速度依存性がより明確であり, 通常の試験片により求められ る破断伸びのひずみ速度依存性とほぼ同様の様相を呈してい る.よって, 適切な試験片形状と標点間距離を選択すれば, 最 大公称ひずみにより「通常の試験片の破断伸び」を定量的に評 価することが可能であると考えられる.

最後に, $\mathrm{R}$ 部長さ $L=30 \mathrm{~mm}$ の試験片の中断引張試験の結 果から求められた真応力と真ひずみ速度との関係を Fig. 9 に 示す.これは, $L$ の变化より求められる $\mathrm{R}$ 部の平均公称ひず み $e=0.1$ および $e=0.3$ に対応する变位でとれぞれ引張試験を 中断した 2 本の試験片を 1 組として, 前述の解析方法により, $e=0.1$ に执ける值を求めた結果である.

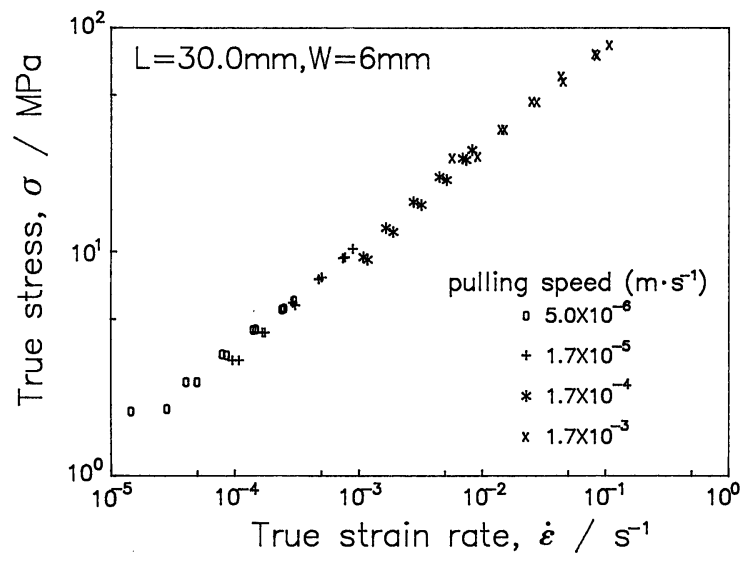

Fig. 9 Relationship between the true stress and the strain rate derived from the results for the interrupt tests of four pairs of the R-type specimens.

図のように，4 組の $\mathrm{R}$ 型試験片により，4 オーダー程度の広 範囲のひずみ速度に物ける真応力-真ひずみ速度関係を求める ことができた．各引張速度に和ける関係は両対数軸上でほぼ直 線で表される. 傾さより $m$ 值を求めてみると, 引張速度 $5.0 \times$ $10^{-6}, 1.7 \times 10^{-5}, 1.7 \times 10^{-4}$ 打よび $1.7 \times 10^{-3} \mathrm{~m} \cdot \mathrm{s}^{-1}$ に対し, 対応する $m$ 值はそれぞれ $0.45,0.53,0.55 .0 .45$ とほぼ妥当な值 が得られた。これは, Region I, III および III (17)の存在を示 すものといえる. しかしながら, 引張速度 $1.7 \times 10^{-5}, 1.7 \times$ $10^{-4}$ の結果がなめらかにつながらず，真ひずみ速度 $10^{-3} \mathrm{~s}^{-1}$ 付近で食い違っている.これは，而章の 3 節で述べたよらに， 主として $\mathrm{R}$ 部が 2 軸応力状態にあるためと考えられ, 今後詳 細な検討が必要である。

\section{N. 結言}

本研究では, 通常の試験片を用いた引張試験による超塑性特 性評価の問題点を整理し，これを踏をえて $\mathrm{R}$ 型試験片による 特性評価について検討した。 その結果， $\mathrm{R}$ 型試験片による超 塑性特性評価の可能性を示す有用な結果を得ることができた。

特に(i)巨大な延性を示す超塑性材料の破断伸びの評価就よび(ii) 試験片内に生じたひずみ速度分布を利用した広範囲のひずみ速 度条件に扣ける真応力-真ひずみ速度関係扣よび $m$ 值の簡便評 価は有用であると考兄られる.

今後, $\mathrm{R}$ 部の 2 軸応力状態の解析, 通常の試験片による結 果との対応関係，結果の再現性等を検討することにより， R 型試験片を用いた引張試験が超塑性特性評価のための極めて有 用かつ簡便な手法となり得るものと期待される.

終わりに，有益な討論をしていただきました大阪大学工学部 の馬越佑吉教授, 石川島播磨重工業の吉利 醇氏ならびに新日 本製鉄の水沼 晋氏に深く感謝致します. また，実験に協力さ れた宇都宮大学大学院生の松本勝生君に感謝の意を表します.

本研究結果の一部は(財)大阪科学技術センター付属ニューマテ リアルセンターの工業技術院委託研究によって得られたもので 
ある。

\section{文献}

(1) N. Furushiro, H. Yamazaki and S. Hori: Trans. ISIJ, $27(1987), 415$

（2）大澤泰明，西村 尚：塑性と加工，27(1986)，375.

（3）次世代金属・複合材料研究開発協会，日本塑性加工学 会, 超塑性材料の特性評価法調查委員会：超塑性材料の 特性評価法飞関する調査報告畫，(1987)，第 4 章.

（4）次世代金属·複合材料研究開発協会, 日本塑性加工学 会, 超塑性材料の特性評価法調查委員会: 超塑性材料の 特性標準化火関する調查報告書, (1988), 第 2 章.

（5）江藤武比古，㕕瀨弥五郎，日野光雄，宮木美光：軽金属 学会第67回秋期大会講演概要，(1984)，47.

(6) Y. Takayama, N. Furushiro, T. Tozawa and H. Kato: Superplasticity in Advanced Materials, Ed. by S. Hori, M. Tokizane and N. Furushiro, The Japan Society for Research on Superplasticity, (1991), 69.

（7）次世代金属·複合材料研究開発協会，日本塑性加工学
会，超塑性材料の特珄評価法調査委員会：超塑性材料の 特性䛨価法に関寸る調查報告書, (1987) $, 9,31$.

(8) JIS Z 2275

(9) ASTM E466-76.

（10）水沼 晋, 吉田清太：理化学研究所報告, 45(1969), 79 .

（11）水沼 晋，吉田清太：塑性と加工，10(1969), 908 .

（12）水沼 晋, 出口重裕, 阿部光延, 速水哲博：鉄之鋼, 66 $(1980), 221$

(13) Y. Uetani, S. Abou, S. Tada and S. Ikeno: Science and Engineering of Light Metals, Ed. by K. Hirano, H. Oikawa and $K$. Ikeda, The Japan Institute of Light Metals, (1991), 953

(14) A. W. Backofen, I. R. Turner and D. H. Avery: Trans. ASM, 57(1964), 980 .

（15）西田正孝:応力集中，森北出版，(1967）, 552，632.

(16) A. Ralston and P. Robinwitz: 户田英男，小野令美共 訳 : 数值解析の理論と応用, ブレイン図畫出版, (1986), 67.

(17) S. W. Zehr and W. A. Backofen: Trans. ASM, 61 (1968), 300.

(18) H. Ishikawa, F. A. Mohamed and T. G. Langdon: Phil. Mag., 32(1975), 1269. 